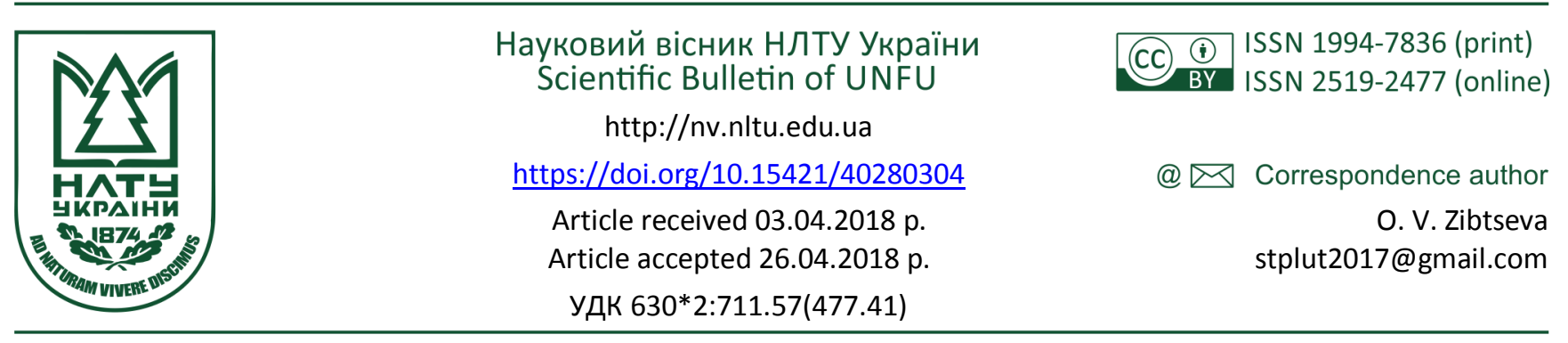

О. В. Зібцева

Національний університет біоресурсів і природокористування Украӥни, м. Київ, Украӥна

\title{
ВИДОВИЙ СКЛАД, СТАН І ДЕКОРАТИВНІСТЬ ДЕРЕВНИХ НАСАДЖЕНЬ НАВЧАЛЬНИХ ЗАКЛАДІВ
}

Визначено видовий склад деревно-чагарникових насаджень на території трьох навчальних закладів малого міста Вишгорода Київської області. Проаналізовано вікову структуру деревних насаджень, їх стан і декоративність. Встановлено, що на дослідних територіях зростає від 24 до 28 деревно-чагарникових видів і форм, а їх загальна кількість дорівнює 49 . На всіх трьох дослідних територіях трапляються 8 деревних видів: Thuja occidentalis, Tilia cordata, Acer platanoides, A. saccharinum, Betula pendula, Juglans regia, Cerasus vulgaris, Prunus divaricata. На двох об'єктах виявлено 12 видів, 29 - тільки на одному. До видів $з$ дуже високою часткою участі на території дослідних об'єктів належать: Ulmus laevis і Populus nigra; Thuja occidentalis і Biota orientalis; Spiraea Thunbergii. Кількість хвойних видів змінюється від 1 до 4. Скрізь присутня Thuјa осcidentalis. Індекс видової різноманітності деревно-кущових рослин для дослідних територій становить від 5,75 до 16,22. Кращі якісні показники на шкільній території має Betula pendula; на території ліцею - Salix purpurea 'pendula', Padus, Hydrangea macrophylla, Thuja occidentalis, Betula pendula, Acer saccharinum, Phus typhina, Philadelphus coronaries; на території гімназіїSpiraea van-Houttei, Salix alba, Populus pyramidalis. Стан деревно-кущових рослин на території двох об'єктів добрий, одного - задовільний. Декоративність насаджень висока на всіх об'єктах. Кращим станом і вищою декоративністю на дослідних територіях відзначаються дерева, які старші від сорокарічного віку.

Ключові слова: деревні види; вікова структура; різноманітність.

Вступ. Насадження на шкільній території належать до категорії зелених насаджень обмеженого користування і мають відповідати чинним нормативам та вимогам щодо озеленення, функціонального зонування території та призначення. Озеленення шкільних територій $є$ обов'язковою умовою екологічного благополуччя (Honcharenko, 2011). Окрім загально визначених функцій, деревні й кущові рослини на шкільній території відіграють роль наочного пізнавального матеріалу, заохочувального фактора в навчанні. Результати останніх досліджень свідчать про те, що зелені насадження впливають на когнітивний розвиток дітей. Високий рівень озеленення шкільної території істотно покращує дитячу пам'ять та уважність (Dadvand et al., 2015).

Ефективно виконувати свої функції спроможні тільки зелені насадження, які перебувають у доброму стані (Battaglia, 2014; Iakushina, 1982). Тому питання видового складу насаджень на шкільних територіях, рівня їх біорізноманіття та реального стану залишаються надзвичайно актуальними.

Мета дослідження - визначити і проаналізувати видовий склад, рівень видової різноманітності, а також стан і декоративність деревних і кущових рослин на територіях навчальних закладів малого міста Вишгорода Київської області.

Матеріал і методи досліджень. Об'єкти досліджень - території трьох навчальних закладів освіти, розташованих у центральній частині малого міста Вишгорода: загальноосвітньої середньої школи № 1, технічного ліцею Національного технічного університету України "КПІ" і Вишгородської районної гімназії "Інтелект" (колишня середня школа № 2). Предмет досліджень - деревні та кущові насадження на територіях освітніх закладів.

Польові дослідження проводили у 2015 і 2017 pp. Під час інвентаризації насаджень, як і в попередніх наших дослідженнях (Zibtseva, 2014; Zibtseva, 2016a), визначали видову приналежність дерев і кущів, вік, стан i декоративність. Стан насаджень визначали за п'ятибальною шкалою візуальної оцінки (з ранжуванням від 1 балу - дерева і кущі у відмінному стані, до 5 балів сухостій), декоративність - за методикою Е. І. Якушиної (Iakushina, 1982). Аналіз даних містив визначення частки участі видів у насадженнях (Zibtseva, 2016a), а також індексів видової різноманітності (SDI) (Sun, 1992). Використали методи інвентаризаційних, біоморфологічних і статистичних досліджень.

Результати дослідження та їх обговорення. Деревні насадження на території загальноосвітньої школи № 1 представлено щільною периметральною рядовою посадкою Ulmus laevis L. віком близько 50 років із північної і південної сторін ділянки, рядовою посадкою старих Populus piramidalis L. (окремі екземпляри 3 яких видалено) з боку головного входу до школи, букетними посадками Thuja occidentalis L. вздовж шкільного майданчика, рештками старого запущеного шкільного

Інформація про автора:

Зібцева Ольга Василівна, канд. с.-г. наук, доцент. Email: stplut2017@gmail.com

Цитування за дсту: Зібцева О. В. Видовий склад, стан і декоративність деревних насаджень навчальних закладів. Науковий вісник НЛтУ України. 2018, т. 28, № 3. С. 22-25.

Citation APA: Zibtseva, O. V. (2018). Species Composition, Condition and Ornamental State of Tree Plantations of Educational Institution. Scientific Bulletin of UNFU, 28(3), 22-25. https://doi.org/10.15421/40280304 
плодового саду в південній частині ділянки, рядовими посадками Amorpha fruticosa L., живоплотами вздовж доріжок та окремими груповими та одиничними посадками дерев і кущів, а також не видаленим молодим природним поновленням деревних рослин, поширеним із західної і південної сторін навколо будівлі школи (Zibtseva, 2016a, 2016b).

За результатами проведеної інвентаризації в озелененні території школи № 1 представлено 28 видів рослин, зокрема 20 видів дерев і 8 чагарникових видів. На шкільній території переважають Ulmus laevis $(37,7$ \% від загальної кількості дерев і кущів та 48,9 \% від кількості дерев за рахунок периметральної рядової посадки), Populus nigra L. (12,8 \% за рахунок молодого природного поновлення), Ligustrum vulgare L. (7,5 \%, за рахунок живоплотів), Tilia cordata Mill. (4,8\%), Spiraea douglasii Hook. (4,8 \%), Acer platanoides L. (4,2\%) i Malus domestica Mill. (4,2\%) (табл.).

Табл. Видова структура деревно-кущових насаджень на території навчальних закладів у м. Вишгороді, \%

\begin{tabular}{|l|c|c|c|}
\hline \multicolumn{1}{|c|}{ Видова назва } & \multicolumn{3}{|c|}{ Частка участі виду, \% на території } \\
\cline { 2 - 4 } & школи & ліцею & гімназії \\
\hline Thuja occidentalis & 1,9 & 20,6 & 5,7 \\
\hline Acer platanoides & 4,2 & 4,2 & 4,4 \\
\hline Tilia cordata & 4,8 & 0,6 & 5,4 \\
\hline Prunus cerasus & 1,1 & 3,6 & 2 \\
\hline Juglans regia & 1,5 & 2,4 & 0,3 \\
\hline Betula pendula & 0,8 & 0,6 & 2,7 \\
\hline Acer saccharinum & 0,8 & 0,6 & 0,7 \\
\hline Spiraea van-Houttei & 0,4 & 6,6 & 0,3 \\
\hline Populus nigra & 12,8 & & 2,7 \\
\hline Ligustrum vulgare & 7,5 & & 6,7 \\
\hline Aesculus hyppocastanum & & 1,8 & 6,1 \\
\hline Syringa vulgaris & & 5,4 & 3 \\
\hline Acer negundo & 1,9 & & 4,4 \\
\hline Picea abies & & 1,8 & 3 \\
\hline Prunus armeniaca & 0,4 & 3,6 & \\
\hline Rosa & & 1,8 & 2,3 \\
\hline Pyrus communis & 1,9 & & 0,7 \\
\hline Philadelphus coronarius & & 0,6 & 1,7 \\
\hline Rosa canina & 1,5 & & 0,3 \\
\hline Prunus domestica & 0,4 & 0,6 & \\
\hline Ulmus laevis & 37,7 & & \\
\hline Spiraea Thunbergii & & & 14,1 \\
\hline Biota orientalis & & 12,7 & \\
\hline Populus pyramidalis & & & 9,1 \\
\hline Padus & & & \\
\hline Weigela & & & \\
\hline Cornus alba & & & \\
\hline Cornus mas & & & \\
\hline Buxus sempervirens & & & \\
\hline Spiraea douglasii & & & \\
\hline Prunus divaricata & & & \\
\hline Malus domestica & & & \\
\hline Phus typhina & & & \\
\hline Amorpha fruticosa & & & \\
\hline Ribes & & & \\
\hline Salix alba & & & \\
\hline Symphoricarpus albus & & & \\
\hline Robinia pseudoacacia & 1,9 & & \\
\hline Acer pseudoplatanus & 1,5 & & \\
\hline Cornus alba & & & \\
\hline Hydrangea macrophylla & & & \\
\hline Pinus sylvestris & & & \\
\hline Ulmus pumila & & & \\
\hline Populus piramidalis & & & \\
\hline Salix purpurea 'pendula' & & & \\
\hline Ulmus scabra & & & \\
\hline Berberis Thunbergii & & & \\
\hline Tilia platiphyllos & & & \\
\hline Cornus albaf. & & & \\
\hline
\end{tabular}

До видів 3 дуже високою часткою участі (понад 10 \%) належать два види (враховуючи природне поновлення) - Ulmus laevis i Populus nigra; 3 високою часткою участі (від 5 до $10 \%$ ) - тільки Ligustrum vulgare; із середньою (від 1 до $5 \%$ включно) - п'ятнадцять видів; 3 низькою (від 0,5 до $1 \%$ ) - три види; $з$ дуже низькою часткою участі (до 0,5 \%) - п'ять. Серед природного поновлення деревних рослин є найпоширеніший самосів Acer platanoides, A. negundo L., A. pseudoplatanus L. та Populus nigra. Серед деревних видів 11 (55\% видового складу) - аборигенні. Серед чагарникових аборигенних 4 (50 \%) види. Хвойні представлено тільки одним інтродукованим деревним видом - Thuja occidentalis.

Деревні насадження на території ліцею представлено щільною рядовою посадкою Thuja occidentalis 3 окремими екземплярами Biota orientalis Endl. і одним екземпляром Pinus sylvestris L. вздовж головного входу (по периметру газону) висотою близько 2 м віком 10 років, а також поодинокими деревами, переважно по периметру і з боку протилежного входу до будівлі ліцею. Зокрема трапляються дерева старшого віку (3050 років) Acer platanoides, високодекоративна букетна посадка $A$. saccharinum L. (віком близько 40 років), Aesculus hyppocastanum L., Betula pendula Roth., Prunus armeniaca L., 20-річні дерева Cerasus vulgaris Mill., Prunus domestica L., Tilia cordata, Juglans regia L., Phus typhina L., а також молоді посадки Padus Mill. і Picea abies Karst. Кущові рослини представлено старшими посадками (10-20 років) Syringa vulgaris L., Spiraea vanHouttei Zab., надзвичайно розкішною високодекоративною букетною посадкою Philadelphus coronaries L. і молодими (віком до 10 років) посадками Buxus sempervirens L., Weigela L., високодекоративним екземпляром Salix purpurea L. 'pendula', Hydrangea macrophylla L., Ribes L. i Rosa L.

Усього на території ліцею виявлено 24 деревно-кущові види та форми: 16 дерев і 9 кущів. До видів 3 дуже високою часткою участі належать Thuja occidentalis i Biota orientalis; $з$ високою - п'ять декоративних чагарникових видів (переважно красиво квітучих); iз середньою - одинадцять; 3 низькою часткою участі шість видів. На території виявлено 4 хвойні деревні види. Загалом серед дерев 7 (або 44 \% від загальної кількості) аборигенних видів, 3 них 2 хвойні. Серед кущів тільки один (або 11 \%) аборигенний вид, більшість - iнтродуковані види та їх декоративні форми.

Переважають 10-річні дерева (26,5 \%), кількість дерев і кущів віком до 15 років становить $35,7 \%$, старших (50 років і більше) - 0,6\%, кількість решти в 5-річних класах віку змінюється в межах від 1,8 до 4,2 \%.

На території гімназії "Інтелект" деревні насадження розташовані переважно по периметру і вздовж будівлі, а кущові посадки - у вигляді живоплотів уздовж доріжок. Найдекоративніше виглядають букетні посадки Thuja occidentalis (аналогічні посадкам на території школи № 1), букетні посадки Cornus mas L., а також Picea abies у внутрішньому дворі гімназії (в одному метрі від будівлі) і навпаки, низькодекоративно-кроновані 50pічні Populus pyramidalis i Acer saccharinum, а також недоглянуті живоплоти з Spiraea van-Houttei під вікнами 3 північно-східного боку школи. Порівняння території гімназії у динаміці за даними супутникової зйомки показало зменшення зелених насаджень тільки в останній 
посадці. Із всихаючих деревних рослин є тільки кронований Acer saccharinum і окремі екземпляри молодих посадок. Усього на території гімназії виявлено 27 видів: 16 деревних і 11 чагарникових. До видів із дуже високою часткою участі (понад $10 \%$ ) належить тільки Spiraea Thunbergii Sieb.; 3 високою часткою участі - сім видів: Aesculus hyppocastanum, Tilia cordata, Populus pyramidalis; Thuja occidentalis, Ligustrum vulgare, Cornus alba L., C. Mas; із середньою - дванадцять видів; з низькою - два види; з дуже низькою часткою участі - п'ять. На території гімназії спостерігаємо природне поновлення Acer negundo, Prunus divaricata Ledeb., Juglans regia, Cerasus vulgaris, Populus nigra, Parthenocissus quinquefolia Planch., Salix alba i Tilia cordata. Серед деревних рослин 9 (або 56\%) аборигенних видів, із них 1 хвойний. Серед чагарникових видів тільки 2 (або $18 \%$ ) аборигенні, хвойних немає.

На всіх трьох дослідних територіях трапляються 8 деревних видів: Thuja occidentalis (однак на території школи і гімназії це переважно 40-річні дерева, а на території ліцею - молоді 10-річні посадки), Tilia cordata, Acer platanoides, A. saccharinum, Betula pendula (ці чотири види представлено деревами переважно старше 45-річного віку), Juglans regia, Cerasus vulgaris, Prunus divaricata (віком близько 20 років). На двох об'єктах трапляються 12 видів, 29 - тільки на одному. Індекс видової різноманітності дерев для шкільної території становить 5,75; для території ліцею - 11,52; для території гімназії - 16,22, тобто наближується до оптимального.

3 результатами аналізу вікової структури насаджень встановлено, що на території школи № 1 переважають тридцяти- і шестидесятирічні деревні рослини (рис.), на які в сумі припадає понад 75 \% екземплярів. На території ліцею переважають молоді посадки до десяти років (32\% рослин). На території гімназії також переважають молоді посадки, зокрема на десятирічні припадає $39 \%$, а на двадцятирічні - $28 \%$ рослин.

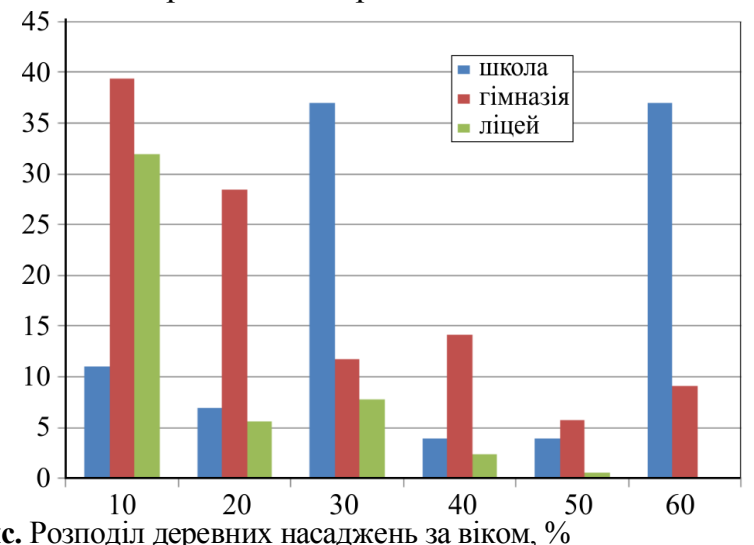

Щодо якісних показників деревних насаджень, то кращим станом і декоративністю на шкільній території відзначаються старші, - сорока- і шістдесятирічні насадження, гіршим (на рівні задовільного) - двадцятирічні й сорокап'ятирічні. Найкращим (відмінним) станом на території ліцею відрізняються 25-30-річні та 50-річні дерева, найнижчим (але добрим) станом і задовільною декоративністю - молоді 5-річні посадки. Між віком і станом та декоративністю на цій території встановлено досить щільний зворотній зв'язок (r = -0,659 і -0,730 відповідно).

На території гімназії немає вираженої залежності між віком і станом та декоративністю рослин, хоча найвищий середній бал декоративності мають 35-річні деревні рослини. Кращими якісними показниками на шкільній території відзначаються Betula pendula і п'ять чагарникових видів; на території ліцею - одинадцять видів, серед яких як молоді посадки декоративних видів (Salix purpurea 'pendula', Padus, Hydrangea macrophylla, Thuja occidentalis), так і найстарші дерева (Betula pendula, Acer saccharinum), а також Phus typhina, Philadelphus coronaries; на території гімназії - Spiraea van-Houttei, Salix alba, Populus pyramidalis.

Середні показники стану і декоративності шкільних насаджень дорівнюють відповідно $2,6^{ \pm 0,12}$ i $1,3^{ \pm 0,07}$ (стан ближче до задовільного, декоративність висока). Середньозважений бал стану деревно-кущових рослин на території ліцею дорівнює 1,7 (стан переважно добрий), декоративності - 1,4 (тобто високий). Середній бал стану деревно-кущових рослин на території гімназії $2,3^{ \pm 0,10}$ (добрий), середній бал декоративності $-1,8^{ \pm 0,10}$, тобто достатньо високий.

\section{Висновки}

1. Кількість видів і форм деревно-чагарникових рослин у насадженнях на території дослідних навчальних закладів змінюється від 24 до 28. Загалом на території трьох навчальних закладів виявлено 49 видів і форм деревних і кущових рослин, з яких вісім трапляються на всіх дослідних територіях, дванадцять - на двох і 29 тільки на одній.

2. До видів 3 дуже високою часткою участі (понад $10 \%$ ) на шкільній території належать два види - Ulmus laevis і Populus nigra; на території ліцею-Thuja occidentalis i Biota orientalis; на території гімназії - тільки один чагарниковий вид - Spiraea Thunbergii.

3. Індекс видової різноманітності деревних рослин для шкільної території становить 5,75; для території ліцею - 11,52; для території гімназії - 16,22, тобто тільки в останньому випадку наближується до оптимального.

4. Стан деревно-кущових рослин на території ліцею і гімназії добрий, школи - задовільний. Декоративність насаджень досить висока на всіх трьох дослідних об'єктах. Кращим станом і вищою декоративністю відзначаються переважно дерева, які старші від сорокарічного віку.

\section{Перелік використаних джерел}

Battaglia, M. (2014). It's not easy going green: obstacles to tree planting. Retrieved from: https://www.fs.fed.us/nrs/pubs/.../nrs_2014_battaglia_001.pdf

Dadvand, P., Nieuwenhuijsen, M. J., Esnaola, M., Forns, J., Basagaña, X., Alvarez-Pedrerol, M., Rivas, I., López-Vicente, M., Castro Pascual, M., Su, J., Jerrett, M., Querol, X., Sunyer, J. (2015). Green spaces and cognitive development in primary schoolchildren, 112(26), 7937-7942, PNAS June 30, 2015; published ahead of print June 15, 2015. https://doi.org/10.1073/pnas.1503402112

Honcharenko, H. Ye. (2011). Monitorynh zovnishnoho ozelenennia zahalnoosvitnikh navchalnykh zakladiv. [Monitoring of indoor greening of general educational institutions]. Retrieved from: http://dspace.udpu.org.ua:8080/jspui/bitstream/6789/1138/1/goncha renko prurodni nauki 3.pdf. [In Ukrainian].

Iakushina, E. I. (1982). Drevesnye rasteniia v ozelenenii Moskvy. [Tree plants in Moscow greening]. Moscow: Nauka. 158 p. [In Russian].

Sun, W. Q. (1992). Quantifying species diversity of streerside trees in our cities. Journal of Arboriculture, 18(2), 91-93.

Zibtseva, O. V. (2014). Vulychni nasadzhennia m. Vyshhoroda Kyivskoi obl. [Street plantings of Vyshgorod t., Kyiv region]. Naukovyi visnyk NUBiP Ukrainy, 198(2), 250-256. [In Ukrainian]. 
Zibtseva, O. V. (2016a). Vydovyi sklad derevno-chaharnykovykh nasadzhen na terytorii shkoly u m. Vishhorodi Kyivskoi obl. [The species composition of tree and shrub plantings at the school territory in Vyshgorod town of Kiev region]. Retrieved from: http://journals.nubip.edu.ua/index.php/Dopovidi/article/view/6845. [In Ukrainian].
Zibtseva, O. V. (2016b). Stan derevnykh nasadzhen na terytorii shkoly $N 1 \mathrm{~m}$. Vishhoroda (Kyivska obl.). [The state of tree plantings at the school N 1 territory in Vyshgorod town (Kiyv region)]. Retrieved from:

http://journals.nubip.edu.ua/index.php/Dopovidi/article/view/7003. [In Ukrainian].

\title{
Национальный университет биоресурсов и природопользования Украины, г. Киев, Украина \\ ВИДОВОЙ СОСТАВ, СОСТОЯНИЕ И ДЕКОРАТИВНОСТЬ ДРЕВЕСНЫХ НАСАЖДЕНИЙ УЧЕБНЫХ ЗАВЕДЕНИЙ
}

\begin{abstract}
Определен видовой состав древесно-кустарниковых насаждений на территории трех учебных заведений малого города Вышгорода Киевской области. Проанализирована возрастная структура древесных насаждений, их состояние и декоративность. Установлено, что на исследуемых территориях произрастает от 24 до 28 древесно-кустарниковых видов и форм, а их общее количество равно 49. На всех трех исследуемых территориях встречается 8 древесных видов: Thuja occidentalis, Tilia cordata, Acer platanoides, A. saccharinum, Betula pendula, Juglans regia, Cerasus vulgaris, Prunus divaricata. На двух объектах встречается 12 видов, 29 - только на одном. К видам с очень высокой долей участия на территории исследованных объектов относятся Ulmus laevis и Populus nigra; Thuja occidentalis и Biota orientalis; Spiraea Thunbergii. Количество хвойных видов колеблется от 1 до 4. Везде присутствует Thuja occidentalis. Индекс видового разнообразия древесно-кустарниковых растений для исследуемых территорий колеблется в пределах от 5,75 до 16,22. Лучшие качественные показатели на школьной территории имеет Betula pendula; на территории лицея - Salix purpurea 'pendula', Padus, Hydrangea macrophylla, Thuja occidentalis, Betula pendula, Acer saccharinum, Phus typhina, Philadelphus coronaries; на территории гимназии - Spiraea van-Houttei, Salix alba, Populus pyramidalis. Состояние древесно-кустарниковых растений на территории двух объектов хорошее, одного - удовлетворительное. Декоративность насаждений высокая на всех объектах. Лучшим состоянием и высшей декоративностью на исследуемых территориях отличаются деревья старше сорокалетнего возраста.
\end{abstract}

Ключевые слова: древесные виды; возрастная структура; разнообразие.

O. V. Zibtseva

National University of Life and Environmental Sciences of Ukraine, Kyiv, Ukraine

\section{SPECIES COMPOSITION, CONDITION AND ORNAMENTAL STATE OF TREE PLANTATIONS OF EDUCATIONAL INSTITUTION}

Species composition of tree and shrub plantings on the territory of educational institutions in Vyshgorod town, Kyiv region, Ukraine, has been defined. The age structure, condition and ornamental state of the tree plantations were analyzed. The number of tree and shrub species and their forms present at the researched territories are found to range from 24 to 28 items and their total quantity is 49. Eight tree species are present in all three of the researched areas, namely Thuja occidentalis, Tilia cordata, Acer platanoides, Acer saccharinum, Betula pendula, Juglans regia, Cerasus vulgaris and Prunus divaricata. Twelve species are present in two out of three of the researched areas, and 29 species are only present at one of the three researched areas. Species with very high participation on the different researched territories are Ulmus laevis and Populus nigra, Thuja occidentalis and Biota orientalis, Spiraea Thunbergi. The number of conifer species ranges from one to four. Thuja occidentalis is present on all three researched areas, namely Species Diversity Index (SDI) of shrubs and ligneous plants for the researched areas ranges from 5.75 to 16.22. The best state and the highest ornamental state on the researched areas are presented by trees over the age of forty. Betula pendula and five shrub species have the best qualitative indicators on the territory of school; on the lyceum territory the best qualitative indicators are presented by Salix purpurea 'pendula', Padus, Hydrangea macrophylla, Thuja occidentalis, Betula pendula, Acer saccharinum, Phus typhina, Philadelphus coronaries; on the territory of gymnasium the best qualitative indicators are presented by Spiraea VanHouttei, Salix alba, Populus pyramidalis. Thirty and sixty-year old trees prevail on the territory of school, up to ten-year old trees prevail on the territory of lyceum, twenty - twenty-five-year old trees prevail on the territory of gymnasium. The state of tree and bush plants on the territory of two objects is good; on the territory of one object it is satisfactory. Ornamental state of trees and shrubs is good in all three researched objects.

Keywords: tree species; age structure; diversity. 